\title{
Uji Senyawa Taurin Sebagai Antikanker Terhadap Jumlah Sel-Sel Leukosit Dan Sel-Sel Eritrosit Mencit (Mus musculus L.) yang Diinduksi Benzo (A) Pyren Secara In Vivo
}

\section{Taurine For Anticancer With Reference To The Total Count Of Leucocyte Cells And Erythrocyte Cells Of Mice (Mus musculus L.) Induced To Benzo (A) Pyrene In Vivo}

\author{
Agra Maysa $^{1 *}$, E. L. Widiastuti ${ }^{2}$, N. Nurcahyani ${ }^{2}$, H. Busman ${ }^{2}$ \\ ${ }^{1}$ Mahasiswa Jurusan Biologi - FMIPA Universitas Lampung - Bandar Lampung \\ ${ }^{2}$ Dosen Jurusan Biologi - FMIPA Universitas Lampung - Bandar Lampung \\ Jl. Prof. Dr Sumatribrojonegoro No. 1. Bandar Lampung, 35145 \\ Email:agra.maysa@yahoo.co.id
}

\begin{abstract}
The aim of this research was to determine the effect of taurine supplementation on the total count of leucocyte cells and erythrocyte cells of mice that have been induced to benzo ( $\alpha$ ) pyrene in vivo. The parameters of this experiment were the total count of leucocyte cells and erythrocyte cells of mice (Mus musculus L.). This experiment was conducted in a complete randomized design by using six treatments, each in five replications. The mice were divided into six groups. Group I used as control were not given any treatment. Group II were given $0,2 \mathrm{~mL}$ of oleum olevarum (olive oil) orally to the end of the experiment. Group III were induced to benzo ( $\alpha$ ) pyrene without being given any taurine. Group IV were given 7,8 $\mathrm{mg} / \mathrm{bw}$ of taurine before being induced to benzo ( $\alpha$ ) pyrene. Group $V$ were given 7,8 $\mathrm{mg} / \mathrm{bw}$ of taurine after being induced to benzo ( $\alpha$ ) pyrene. Group VI were given 15,6 $\mathrm{mg} / \mathrm{bw}$ of taurine after being induced to benzo ( $\alpha$ ) pyrene. Mice of group III, V, and VI were injected with 0,5 $\mathrm{mL}$ of benzo ( $\alpha$ ) pyrene solution every day for 10 days on their subcutant tissue for the purpose of a nodule being formed in this area. It was then continued by giving taurine orally for 15 days. In the final treatment, mice blood was taken to count the leucocyte cells and erythrocyte cells. The data were analyzed using ANOVA (Analysis of Variance) then continued by calculating least significant difference at 5 per cent level of significance. The results indicated that taurine had the ability to reduce leucocyte cells into its normal quantity, and was able to increase the number of erythrocyte cells of mice suffered from leukaemia back to normal.
\end{abstract}

Key words: benzo ( $\alpha$ ) pyrene, leukaemia, leucocyte, mice, taurine

Diterima: 27 Desember 2015, disetujui 26 Maret 2016

\section{PENDAHULUAN}

Kanker merupakan penyebab kematian yang menempati peringkat ke dua setelah penyakit jantung (American Cancer Society, 2010). Kanker dapat disebabkan oleh beberapa faktor, di antaranya factor 

genetik, penyakit, dan hormon (Mosmann, 1993; Hanahan dan Weinberg, 2000). Kanker terjadi akibat hilangnya mekanisme kontrol sel yang menyebabkan tidak normalnya pertumbuhan jaringan. Hilangnya mekanisme kontrol sel dapat disebabkan oleh beberapa faktor, di antaranya adalah virus serta beberapa reaksi fisika dan kimia, termasuk paparan radikal bebas. Faktor-faktor tersebut menyebabkan terjadinya transformasi sel normal menjadi sel kanker. Selanjutnya, sel kanker tersebut akan membelah diri sehingga terbentuk sel-sel kanker lainnya (Syarif, 1995). Kanker dapat terjadi pada semua jaringan, termasuk pada jaringan darah yang disebut dengan leukemia.

Leukemia merupakan penyakit yang ditandai dengan terjadinya diferensiasi dan proliferasi sel induk haematopoietik yang mengalami transformasi dan menjadi ganas, menyebabkan terjadinya supresi dan penggantian elemen sumsum normal (Baldy, 2006). Leukemia ditunjukkan dengan adanya akumulasi sel darah putih muda (immature white blood cells) yang abnormal di dalam pembuluh darah (Kleinsmith, 2006).

Kanker pada umumnya disebabkan oleh paparan suatu karsinogen yang terjadi secara berulang kali dan aditif dengan dosis tertentu, meski tidak menutup kemungkinan dapat timbul dari karsinogen dosis tunggal (Archer, 1992). Benzo ( $\alpha$ ) pyren merupakan senyawa hidrokarbon polisiklik aromatik yang digolongkan sebaga senyawa pro karsinogen kuat yang mampu merusak DNA dan menimbulkan mutasi gengen pengatur pertumbuhan. Larutan benzo ( $\alpha$ ) pyren tersebut akan disuntikkan kepada hewan uji untuk menginduksi kanker (Yana, 2009). Pengobatan untuk keganasan haematologi selama beberapa dekade terakhir di antaranya adalah pembedahan, kemoterapi, dan terapi radiasi (Baldy, 2006).

Taurin (2-aminoethane sulphonic acid) merupakan asam amino esensial bebas yang ditemukan melimpah pada jaringan hewan (Ismail, Suheryanto, Kustomo, dan Harsono, 2005). Taurin ditemukan melimpah di sitosol leukosit (Learn, Fried, dan Thomas, 1990). Beberapa studi in vitro menunjukkan bahwa rendahnya level taurin pada tubuh berbagai spesies hewan berkaitan dengan timbulnya beragam penyakit patologis, seperti kardiomiopati, degenerasi retina, serta pertumbuhan yang terhambat. Adapun peran metabolik taurin di antaranya adalah konjugasi asam empedu, detoksifikasi, stabilisasi membran, osmoregulasi, dan modulasi kadar kalsium pada sel. Taurin telah digunakan secara klinis dalam pengobatan berbagai penyakit seperti penyakit kardiovaskuler, hiperkolesterolemia, epilepsi, alzheimer, gangguan hati, alkoholisme, dan fibrosis, dengan tingkat keberhasilan yang beragam (Birdsall, 1998). Dari latar belakang tersebut, taurin diharapkan mampu bekerja dalam mereduksi sel-sel kanker atau setidaknya bereaksi secara antagonis terhadap sel-sel kanker pada jaringan darah dengan mengujicobakannya pada hewan percobaan yang telah terinduksi zat kanker.

Pengobatan leukemia tidak bisa dilakukan dengan operasi, sebab darah menyebar ke seluruh bagian tubuh. Kleinsmith (2006) menyatakan bahwa pengobatan dengan cara kemoterapi mampu menyembuhkan leukemia jenis tertentu, namun kebanyakan dari jenis obat yang digunakan akan bekerja dengan menghambat replikasi DNA, merusak DNA, atau menghalangi proses pembelahan sel, di mana hal tersebut akan berbahaya bagi proses pembelahan sel normal. Obat tersebut juga bersifat toksik bagi sum-sum tulang dan saluran gastrointestinal. Selain itu, dosis obat yang dibutuhkan untuk membunuh sel-sel kanker akan memicu efek toksik yang besar.

Taurin diketahui memiliki peran fisiologis dalam konjugasi asam empedu, detoksifikasi, dan stabilisasi membran. Taurin juga telah digunakan dalam berbagai pengobatan seperti penyakit kardiovaskuler, degenerasi retina, diabetes, kelainan hepatik, dan alzheimer, dengan hasil yang beragam. Beberapa pengecualian, pemberian taurin kepada manusia dan hewan bersifat aman meski diberikan dalam dosis tinggi (Birdsall, 1998).

Masalah yang dipaparkan pada penelitian ini adalah apakah senyawa taurin mampu bekerja sebagai antikanker dalam mereduksi sel darah putih abnormal sehingga mengembalikan leukosit dan eritrosit ke jumlah normal. Penelitian ini bertujuan untuk mengetahui efek pemberian taurin terhadap jumlah leukosit dan eritrosit pada mencit yang telah diinduksi benzo $(\alpha)$ pyren secara in vivo. 


\section{METODE}

Penelitian ini dilaksanakan pada bulan April - Mei 2015. Penginduksian zat karsinogen dan pemberian taurin kepada hewan uji dilaksanakan di Laboratorium Biologi Molekuler, Jurusan Biologi, Fakultas Matematika dan Ilmu Pengetahuan Alam, Universitas Lampung. Perhitungan jumlah sel leukosit dan sel eritrosit dilakukan di Laboratorium Patologi di Balai Pengujian dan Penyidikan Veteriner (BPPV) Regional III Bandar Lampung. Alat dan bahan yang digunakan dalam penelitian ini terdiri dari: bak berbahan plastik berukuran $20 \times 30 \mathrm{~cm}$ sebanyak 30 buah sebagai wadah pemeliharaan mencit, tempat minuman dan tempat pakan serta tutup dari kawat, neraca analitik, kertas label, tissue, jarum suntik, sonde, pemanas air dan panci untuk sterilisasi jarum suntik, gelas objek, pipet Thoma, kamar hitung, mikroskop, blood counter tabulator, tutup glass counter, gunting, pipet tetes, plat tetes, pisau, haemositometer, dan kamera digital. Adapun bahan yang digunakan yaitu 30 ekor mencit (Mus musculus) jantan dari galur khusus yang berumur 5-7 minggu, pakan mencit Par G, air mineral untuk minum mencit, oleum olivarum, benzo $(\alpha)$ pyren, aquadest, larutan Hayem $(\mathrm{NaCl} 1 \mathrm{~g}+\mathrm{Na} 2 \mathrm{SO} 45 \mathrm{~g}+\mathrm{HgCl} 20,5 \mathrm{~g}+$ aquadest $200 \mathrm{~mL}$ ), larutan Turk (asam asetat $13 \mathrm{~mL}+$ gentiana violet $21 \mathrm{~mL}+$ aquadest $100 \mathrm{~mL}$ ), taurin, ethylenediamine-tetraacetic acid (EDTA) sebagai antikoagulan untuk mencegah pembekuan darah, dan giemsa. Penelitian ini dilakukan dengan menggunakan Rancangan Acak Lengkap (RAL) dengan enam jenis perlakuan. Masing-masing perlakuan menggunakan lima pengulangan. Perlakuan yang diberikan yaitu: Perlakuan 1 : Tidak diberi perlakuan (kontrol); Perlakuan 2 : Diberi 0,2 $\mathrm{mL}$ Oleum olivarum dan aquadest sampai akhir masa penelitian (kontrol negatif); Perlakuan 3 : Diinduksi $0,5 \mathrm{~mL}$ larutan benzo $(\alpha)$ pyren tanpa pemberian taurin (kontrol positif); Perlakuan 4 : Diberi taurin $7,8 \mathrm{mg} / \mathrm{bb}$ mencit setiap hari selama dua minggu, kemudian diinduksi 0,5 $\mathrm{mL}$ larutan benzo $(\alpha)$ pyren selama 10 hari (preventif); Perlakuan 5 : Setelah diinduksi $0,5 \mathrm{~mL}$ larutan benzo ( $\alpha$ ) pyren, diberi taurin 7,8 mg/bb mencit selama 15 hari (dosis I); Perlakuan 6 : Setelah diinduksi 0,5 mL larutan benzo $(\alpha)$ pyren, diberi taurin $15,6 \mathrm{mg} / \mathrm{bb}$ mencit selama 15 hari (dosis 2 ).

\section{Prosedur kerja}

Langkah pertama adalah mempersiapkan mencit: Mencit yang digunakan adalah mencit jantan dari galur khusus berumur 5-7 minggu sebanyak 30 ekor dan ditempatkan di wadah yang terpisah, dengan masing-masing wadah berisi satu ekor mencit. Mencit diaklimatisasi selama 15 hari agar beradaptasi dengan kondisi kandang, dengan diberi pakan Par G dan minuman air mineral secara ad libitum (sampai kenyang). Masing-masing mencit diusahakan agar kondisi kekebalan tubuhnya sama. Langkah kedua adalah mempersiapkan taurin: Taurin yang digunakan sesuai dengan dosis yang biasa digunakan oleh manusia yaitu $3 \mathrm{gr} / 70 \mathrm{~kg}$ berat badan manusia, kemudian dikonversi ke mencit dengan nilai 0,0026 menurut tabel konversi Suhardjono (1995). Hasil konversi yang diperoleh dari perhitungan $3000 \mathrm{mg}$ dikali dengan 0,0026 adalah 7,8 $\mathrm{mg} / \mathrm{bb} / \mathrm{hari}$. Dosis yang digunakan untuk pengujian adalah 7,8 dan 15,6 mg/bb/hari. Langkah ketiga adalah Induksi zat karsinogen dilakukan dengan menyuntikkan larutan benzo $(\alpha)$ pyren pada jaringan subkutan mencit di bagian tengkuk. Larutan karsinogenik diperoleh dengan melarutkan $0,3 \mathrm{~g}$ benzo $(\alpha)$ pyren dengan 0,2 $\mathrm{mL}$ Oleum olivarum (Saputri, Dyah, dan Abdulgani, 2006). Injeksi larutan karsinogenik dilakukan setiap hari selama 10 hari. Setelah itu, mencit diberi larutan taurin dengan cara dicekok selama 15 hari. Langkah ketiga adalah Induksi zat karsinogen dilakukan dengan menyuntikkan larutan benzo $(\alpha)$ pyren pada jaringan subkutan mencit di bagian tengkuk. Larutan karsinogenik diperoleh dengan melarutkan 0,3 g benzo ( $\alpha$ ) pyren dengan 0,2 mL Oleum olivarum (Saputri, Dyah, dan Abdulgani, 2006). Injeksi larutan karsinogenik dilakukan setiap hari selama 10 hari. Setelah itu, mencit diberi larutan taurin dengan cara dicekok selama 15 hari. Langkah keempat adalah analisis sel darah sel darah putih (leukosit) dan Sel Darah Merah (Eritrosit). 


\section{a. Perhitungan sel darah putih (leukosit)}

Perhitungan leukosit dilakukan dengan menggunakan pipet Thoma leukosit. Sampel darah dihisap sampai angka 0,5, kemudian ujung pipet dicelupkan ke dalam larutan Turk. Larutan Turk dihisap sampai angka 11 sehingga diperoleh pengenceran 1:20. Kemudian kedua ujung pipet ditutup dengan jari dan dibolakbalik dengan membentuk angka delapan selama kurang lebih tiga menit. Larutan suspensi darah kemudian diteteskan, 2-3 tetes pertama dibuang, selanjutnya diteteskan di atas kamar hitung. Setelah ditutup dengan cover glass, preparat didiamkan selama satu menit untuk melisiskan eritrosit. Perhitungan leukosit dilakukan dengan menggunakan mikroskop dengan perbesaran 40 kali pada empat kotak besar kamar hitung. Jumlah leukosit yang ditemukan dikalikan dengan 50 merupakan jumlah leukosit per milimeter kubik $\left(\mathrm{mm}^{3}\right)$ (Tambur, 2006).

\section{b. Perhitungan Sel Darah Merah (Eritrosit)}

Sampel darah dihisap dengan dengan pipet khusus eritrosit hingga angka 0,5. Larutan yang digunakan sebagai suspensi adalah larutan Hayem, dihisap hingga angka 11, kemudian dibolak-balik membentuk angka delapan selama tiga menit agar homogen. Tetesan suspensi darah pertama dan kedua dibuang, kemudian diteteskan ke atas kamar hitung lalu ditutup dengan cover glass. Perhitungan dilakukan di bawah mikroskop dengan menghitung sel yang terlihat di dalam kotak-kotak yang terdapat pada kamar hitung. Jumlah sel leukosit dapat diketahui dengan menghitung sel yang terlihat di dalam empat kotak besar di bagian tepi. Adapun sel eritrostit dapat diketahui jumlahnya dengan menghitung sel yang terlihat di dalam lima kotak berukuran sedang di bagian tengah.

\section{Analisis Data}

Data yang diperoleh dari hasil percobaan dianalisis dengan menggunakan ANOVA (Analysis of Variance) pada taraf uji $\alpha$ 5\%, yang dilanjutkan dengan uji BNT pada taraf $\alpha 5 \%$

\section{HASIL DAN PEMBAHASAN}

\section{A. Jumlah Sel Darah Putih (Leukosit) Mencit}

Pada penelitian ini, jumlah leukosit mencit dijadikan sebagai salah satu parameter dalam uji efektivitas taurin sebagai antikanker pada darah. Jumlah leukosit mencit pada masing-masing kelompok perlakuan disajikan dalam Tabel 1.

Tabel 1. Jumlah leukosit (sel/ $\mu$ darah)

\begin{tabular}{ccccccc}
\hline Perlakuan & Kontrol & KN & KP & Preventif & Dosis 1 & Dosis 2 \\
\hline Rata-rata \pm SEM & $4390 \pm$ & $6590 \pm$ & $15400 \pm$ & $6440 \pm$ & $10900 \pm$ & $8460 \pm 761$ \\
& $1054(\mathrm{a})$ & $330(\mathrm{a})$ & 1878 (b) & 300 (a) & 481 (c) & (a)
\end{tabular}

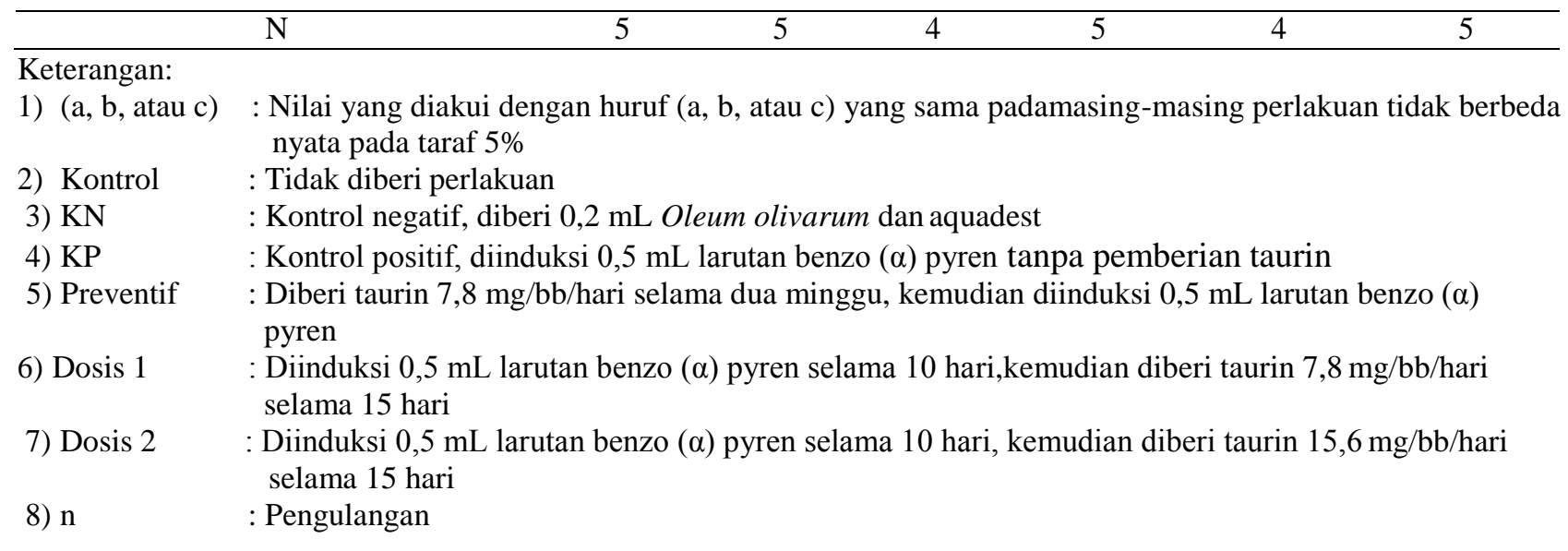


Berdasarkan Tabel 1 menunjukkan bahwa jumlah rata-rata leukosit kontrol positif berbeda secara signifikan dengan jumlah rata-rata dari kelompok perlakuan lainnya. Pada kelompok perlakuan kontrol positif, yaitu kelompok mencit yang diinduksi benzo $(\alpha)$ pyren, diperoleh jumlah rata-rata leukosit paling tinggi hingga mencapai tiga kali lipat dari jumlah rata-rata kelompok kontrol. Tingginya jumlah rata-rata leukosit pada kelompok ini diduga merupakan indikasi terjadinya kanker pada darah, yaitu dengan meningkatnya jumlah leukosit.

Pemberian taurin pada mencit yang diinduksi benzo $(\alpha)$ pyren terlihat mendekati jumlah leukosit pada kelompok kontrol. Namun demikian, jumlah rata-rata leukosit kelompok dosis 1, yaitu yang diberi taurin sebanyak $7,8 \mathrm{mg} / \mathrm{bb} / \mathrm{hari}$, memiliki jumlah leukosit yang lebih tinggi dibandingkan dengan jumlah rata-rata leukosit kelompok kontrol, kontrol negatif, preventif, dan dosis 2. Mencit yang diberi taurin dengan dosis $15,6 \mathrm{mg} / \mathrm{bb} / \mathrm{hari}$ (dosis 2) mengalami penurunan jumlah rata-rata leukosit yang cukup banyak hingga mendekati jumlah rata-rata leukosit kelompok kontrol negatif, yaitu kelompok mencit yang tidak diinduksi benzo $(\alpha)$ pyren.

\section{B. Jumlah Sel Darah Merah (Eritrosit) Mencit}

Jumlah eritrosit mencit pada setiap kelompok perlakuan disajikan dalam Tabel 2. Tabel 2 menunjukkan bahwa pemberian taurin berpengaruh terhadap jumlah total eritrosit pada setiap kelompok perlakuan. Jumlah rata-rata eritrosit kelompok kontrol dan dosis 1 berbeda secara signifikan dengan kelompok kontrol negatif, preventif, dan dosis 2, serta berbeda secara signifikan dengan kelompok kontrol positif.

Tabel 2. Jumlah Eritrosit (sel/ $\mu$ darah)

\begin{tabular}{|c|c|c|c|c|c|c|}
\hline Perlakuan & Kontrol & $\mathrm{KN}$ & KP & Preventif & Dosis 1 & Dosis 2 \\
\hline Rata-rata \pm SEM & $\begin{array}{c}604 \times 10^{4} \pm \\
54,36 \times 10^{4} \\
\text { (a) }\end{array}$ & $\begin{array}{c}776 \times 10^{4} \pm \\
62,98 \times 10^{4} \\
\text { (b) }\end{array}$ & $\begin{array}{c}352 \times 10^{4} \pm \\
14,29 \times 10^{4} \\
\text { (c) }\end{array}$ & $\begin{array}{c}818 \times 10^{4} \pm \\
27,38 \times 10^{4} \\
\text { (b) }\end{array}$ & $\begin{array}{c}657 \times 10^{4} \pm \\
17,86 \times 10^{4} \text { (a) }\end{array}$ & $\begin{array}{c}895 \times 10^{4} \pm \\
38,13 \times 10^{4} \\
\text { (b) }\end{array}$ \\
\hline $\mathrm{n}$ & 5 & 5 & 4 & 5 & 4 & 5 \\
\hline
\end{tabular}

Keterangan:

1) ( $a, b$, atau c) : Nilai yang diakui dengan huruf ( $a, b$, atau c) yang sama pada masing-masing perlakuan tidak berbeda nyata pada taraf $5 \%$

2) Kontrol : : Tidak diberi perlakuan

3) $\mathrm{KN} \quad$ : Kontrol negatif, diberi 0,2 $\mathrm{mL}$ Oleum olivarum dan aquadest

4) KP : Kontrol positif, diinduksi $0,5 \mathrm{~mL}$ larutan benzo $(\alpha)$ pyren tanpa pemberian taurin

5) Preventif : Diberi taurin $7,8 \mathrm{mg} / \mathrm{bb} / \mathrm{hari}$ selama dua minggu, kemudian diinduksi $0,5 \mathrm{~mL}$ larutan benzo $(\alpha)$ pyren

6) Dosis 1 : Diinduksi $0,5 \mathrm{~mL}$ larutan benzo $(\alpha)$ pyren selama 10 hari, kemudian diberi taurin 7,8 mg/bb/hari selama 15 hari

7) Dosis 2 : Diinduksi $0,5 \mathrm{~mL}$ larutan benzo $(\alpha)$ pyren selama 10 hari, kemudian diberi taurin $15,6 \mathrm{mg} / \mathrm{bb} / \mathrm{hari}$ selama 15 hari

8) $\mathrm{n} \quad$ : Pengulangan

Hasil perhitungan darah menunjukkan bahwa jumlah rata-rata eritrosit pada kelompok kontrol positif jauh lebih sedikit dibandingkan dengan jumlah rata-rata eritrosit kelompok lainnya. Jumlah ini berada di bawah jumlah normal eritrosit mamalia, yaitu 5.000 .000 - $6.000 .000 \mathrm{sel} / \mu \mathrm{l}$ darah menurut Campbell (2010). Hal ini diduga sebagai indikasi terjadinya kanker pada darah, yaitu jumlah eritrosit akan menurun sebagai akibat adanya akumulasi sel-sel ganas di sum-sum tulang sehingga menyebabkan berkurangnya sel-sel normal di darah perifer (Fianza, 2007). 
Adapun jumlah rata-rata eritrosit tertinggi ditemukan pada kelompok dosis 2 (diberi taurin dengan dosis $15,6 \mathrm{mg} / \mathrm{bb} /$ hari). Jumlah rata-rata eritrosit pada kelompok ini mengalami peningkatan sebesar $254 \%$ dibanding jumlah rata-rata eritrosit pada kelompok kontrol positif. Jumlah ini juga berada di atas jumlah normal eritrosit mencit. Hal ini diduga merupakan pengaruh dari pemberian taurin dengan dosis tersebut, di mana taurin diduga bereaksi secara antagonis dalam melawan sel kanker dengan hasil yang cukup baik, sehingga jumlah eritrosit pada kelompok ini lebih tinggi dibandingkan dengan jumlah eritrosit pada kelompok kontrol positif (tanpa pemberian taurin) yang juga diduga mengalami leukemia. Leukemia merupakan suatu kelainan pada darah berupa proliferasi patologis sel haematopoetik muda yang ditandai dengan adanya kegagalan sum-sum tulang dalam membentuk sel darah normal (Mansjoer, 2002). Di samping itu, terdapat akumulasi sel darah putih immatur pada sum-sum tulang yang menggantikan elemen sum-sum tulang normal (Smeltzer dan Bare, 2002).

Pada hasil perhitungan sel darah kelompok kontrol positif yang diinduksi senyawa benzo $(\alpha)$ pyren, diperoleh jumlah leukosit yang tinggi dan lebih dari jumlah normal, yaitu $5.000-10.000 \mathrm{sel} / \mu \mathrm{l}$ darah menurut Shrivastava, dkk. (2004). Jumlah leukosit yang tinggi ini disertai dengan jumlah eritrosit yang rendah dan kurang dari jumlah normal, yaitu 5.000 .000 - $6.000 .000 \mathrm{sel} / \mu 1$ darah (Shrivastava dkk., 2004). Hal ini menunjukkan bahwa leukosit tersebut diduga merupakan leukosit abnormal, sehingga mampu menekan jumlah sel darah yang lain (Widmann, 1995), termasuk pembentukan sel-sel darah merah.

Selanjutnya, pada kelompok yang diberi taurin baik sebagai preventif ataupun kuratif (dosis 1 dan 2) menunjukkan adanya pemulihan jumlah sel darah, baik jumlah leukosit maupun eritrosit ke jumlah normal ataupun mendekati normal. Pada kelompok yang diinduksi benzo $(\alpha)$ pyren, terjadi peningkatan jumlah leukosit yang diikuti dengan penurunan jumlah eritrosit, yang menunjukkan adanya kondisi kanker darah pada mencit.

Benzo $(\alpha)$ pyren yang merupakan senyawa hidrokarbon polisiklik aromatik mampu merusak DNA selsel hematopoetik pada sum-sum tulang atau jaringan hematopoetik lainnya. Kerusakan DNA inilah yang menimbulkan kelainan pada gen-gen pengatur pertumbuhan yaitu gen pG3, dan diduga sel-sel sum-sum tulang pun mengalami hal yang serupa (Yana, 2009). Kerusakan yang ditimbulkan oleh benzo $(\alpha)$ pyren yaitu dengan melepaskan radikal bebas yang memiliki kemampuan untuk mengoksidasi molekul-molekul seluler.

Selanjutnya, dengan pemberian taurin, kerusakan ini dapat dihambat atau dikurangi. Penghambatan terlihat dari kelompok pemberian taurin sebelum pemberian benzo $(\alpha)$ pyren dilakukan (antara kelompok preventif dengan kelompok kontrol negatif, Tabel 1). Pemberian taurin pada dosis 1 atau dosis 2 menunjukkan adanya pengurangan pengaruh karsinogenik benzo $(\alpha)$ pyren terhadap jaringan sum-sum tulang atau jaringan hematopoetik.

Taurin bersifat non esensial dan inert secara biologis. Namun, peran-peran fisiologis taurin belum sepenuhnya dapat dijelaskan. Taurin diketahui berperan dalam berbagai fungsi fisiologis seperti neuromodulasi pada sistem saraf pusat, produksi energi, perlindungan terhadap oksidasi, dan immunomodulasi (Eilertsen, dkk., 2012). Schuller-Levis dan Park (2004) menyatakan bahwa Taurin menunjukkan kemampuan dalam proteksi jaringan pada banyak contoh luka yang disebabkan oleh induksi oksidan. Salah satu kemungkinan bahwa taurin yang bereaksi dengan $\mathrm{HOCl}$, menghasilkan taurin kloroamin (Tau-Cl) yang bersifat lebih stabil dan lebih rendah toksisitasnya. Tau-Cl diketahui merupakan regulator kuat pada sistem imun. Lebih spesifik, Tau-Cl mampu mengatur produksi mediator proinflamatori pada rodentia dan manusia.

Taurin diketahui memiliki kemampuan dalam menetralisir asam hipoklorus, yang merupakan subtansi oksidasi, dengan demikian taurin mampu mengurangi kerusakan DNA yang disebabkan oleh senyawa amino aromatik. Taurin juga dilaporkan mampu melindungi tubuh dari toksisitas akibat induksi karbon tetraklorida serta memiliki kemampuan dalam memodifikasi faktor-faktor penyebab kerentanan terhadap bahan kimia 
Jurnal Penelitian Pertanian Terapan

beracun (Ripps dan Shen, 2012). Dengan demikian, taurin diduga mampu bereaksi secara antagonis terhadap benzo $(\alpha)$ pyren yang telah diinduksikan pada tubuh mencit.

\section{KESIMPULAN}

1. Taurin efektif dalam mereduksi jumlah sel-sel leukosit hingga kembali ke jumlah normal,

2. Taurin mampu meningkatkan jumlah sel-sel eritrosit pada mencit yang terkena leukemia hingga kembali ke jumlah normal.

\section{DAFTAR PUSTAKA}

American Cancer Society. 2010. Cancer Statistic 2010. Atlanta, GA: American Cancer Society.

Archer, M. C. 1992. Chemical carcinogenesis. In: Tannock JF, Hill RP, editors. The basic science of oncology. 2nd ed. New York: Mc Graw-Hill, Inc. p. 102-17.

Baldy, C. M. 2006. Gangguan Sel Darah Putih dan Sel Plasma. Dalam: Price, S. A., L. M. Wilson. 2006. Patofisiologi Edisi 6. Jakarta: EGC, 271-284.

Birdsall, T. C. 1998. Therapeutic Applications of Taurine. Alternative Medicine Review, 3(2):128-136.

Campbell, N. A., J. B. Reece, L. A. Urry, M. L. Cain, S. A. Wasserman, P. V. Minorsky, dan R. B. Jackson. 2010. Biologi Edisi Kedelapan Jilid 3. Jakarta: Erlangga.

Eilertsen, K., R. Larsen, H. K. Maehre, I. Jensen, dan E. O. Elvevoll. 2012. Anticholesterolemic and antiatherogenic effects of taurine supplementation is model dependent. Lipoproteins - Role in Health and Diseases. 269-288.

Fianza, P. I. 2007. Leukemia Limfoblastik Akut, Buku Ajar Ilmu Penyakit Dalam Jilid II. Jakarta: Pusat Penerbitan Departemen Ilmu Penyakit Dalam, Fakultas Kedokteran, Universitas Indonesia.

Hanahan, D., R. A. Weinberg. 2000. The Hallmark of Cancer. Cell. Vol 100:57-70.

Ismail N. E., R. Suheryanto, S. Kustomo, W. J. B. Harsono. 2005. Efektifitas Extrajoss dalam Memperbaiki Kinerja Ketahanan Kerja. Badan Penelitian dan Pengembangan Kesehatan Republik Indonesia. Jakarta.

Kleinsmith, L. J. 2006. Principles of Cancer Biology. Michigan: Pearson Education, Inc.

Learn D. B., V. A. Fried, E. L. Thomas. 1990. Taurine and hypotaurine content of human leukocytes. $J$ Leukoc Biol, 48:174-182.

Mansjoer, A. 2002. Askarias, dalam: Kapita Selekta Kedokteran Jilid I, Edisi 3. Jakarta: Media Aesculapius FKUI.

Mosmann, T. 1993. Rapid Colorimetric Assay for Cellular Growth and Survival: Application to Proliferation and Citotoxicity Assays. Journal of Immunological Methods, 65, 55-63.

Ripps, H., W. Shen. 2012. Taurin: A Very Essential Amino Acid. Molecular Vision; 18:2673-2686. 
Agra Maysa dkk: Uji Senyawa Taurin Sebagai Antikanker Terhadap Jumlah Sel-Sel Leukosit ...

Saputri, D. N. E., A. P. Dyah, dan N. Abdulgani. 2006. Jumlah Total dan Diferensial Leukosit Mencit (Mus musculus) pada Evaluasi In Vivo Antikanker Ekstrak Spons Laut Aaptos suberitoides. Skripsi. Fakultas Matematika dan Ilmu Pengetahuan Alam. Institut Teknologi Sepuluh Nopember. Surabaya.

Schuller-Levis, G. B., E. Park. 2004. Taurine and its chloroamine: modulators of immunity. Neurochemical Research. 29 (1): 117-126.

Shrivastava, R., S. Srivastava, R. K. Upreti, and U. C. Chaturvedi. 2005. Effects of dengue virus infection on peripheral blood cells of mice exposed to hexavalent chromium with drinking water. Indian J Med Res. 122; pp 111-119.

Smeltzer. S. C. dan B. G. Bare. 2002. Buku Ajar Keperawatan Medikal Bedah Brunner dan Suddarth Edisi 8, Vol. 1 dan 2. Jakarta: ECG.

Suhardjono, D. 1995. Percobaan Hewan Laboratorium. Yogyakarta: Gajah Mada University Press. hal. 207.

Syarif, A. 1995. Farmakologi dan Terapi. Jakarta: Bagian Farmakologi Fakultas Kedokteran Universitas lndonesia edisi-4.

Tambur, Z. 2006. White Blood Cell Differential Count in Rabbits Artificially Infected with Intestinal Coccidia. J. Protozool. Res, 16, 42-50.

Widmann, F. K. 1995. Tinjauan Klinis Hasil Pemeriksaan Laboratorium Edisi 9. Jakarta: Penerbit Buku Kedokteran EGC.

Yana, S. 2009. Uji Mutagenisitas Benzo (alfa) piren dengan Metode Mikronukleus pada Sumsum Tulang Mencit Albino (Mus musculus). Cermin Dunia Kedokteran, Vol 36 no. 1/167. 